\title{
Isolation and structural determination of a new hydrophobic peptide venepeptide from Streptomyces venezuelae
}

\author{
Shinya Kodani ${ }^{1,2}$, Kazuki Sato ${ }^{1}$, Hikaru $\mathrm{Hemmi}^{3}$ and Mayumi Ohnish-Kameyama ${ }^{3}$ \\ The Journal of Antibiotics (2014) 67, 839-842; doi:10.1038/ja.2014.81; published online 25 June 2014
}

The most important characteristic of streptomycetes is the ability to biosynthesize a wide variety of structurally complex secondary metabolites. In order to clarify biosynthesis and regulation system of useful antibiotic production, whole-genome sequences of numerous streptomycetes have been determined. ${ }^{1,2}$ Accumulated genome data revealed that there are many possible peptide biosynthetic genes including lantibiotics and non-ribosomally biosynthesized peptides in the genomes of streptomycetes. ${ }^{3,4}$ In the model streptomycete Streptomyces coelicolor, lantibiotic-like hydrophobic peptide SapB is known to get involved in induction of the early development process such as aerial hyphae formation. ${ }^{5-9}$ The peptide covers the surface of cells to survive the dry environment along with hydrophobic proteins such as chaplins ${ }^{10,11}$ and rodlins, ${ }^{12,13}$ and stimulates to cause formation of aerial hyphae by lowering the surface tension of agar medium at the same time. ${ }^{14,15}$ The other lantibiotic-like peptides including SapT, ${ }^{16}$ griseopeptin, avermipeptin and erythreapeptin ${ }^{17}$ were isolated and characterized from actinomycetes. However, the numbers of reported peptides are comparatively few than numbers of biosynthetic genes, which can be expected from genome sequences in streptomycetes, so far. Recently, new lantibiotic peptide venezuelin ${ }^{3}$ was characterized by heterogeneous expression of biosynthetic genes based on genome mining, as venezuelin was not produced by Streptomyces venezuelae in normal culture condition. In these circumstances, we conducted chemical investigation to search for new peptide on the extract of $S$. venezuelae. As a result, we isolated and structure-determined a new hydrophobic peptide named venepeptide (1 in Figure 1a) from the $\mathrm{MeOH}$ extract of $S$. venezuelae. In addition, we found the biosynthetic gene of venepeptide from whole-genome data of S. venezuela, and indicated that the analogous genes were distributed over six other streptomycetes. Here we describe isolation and structural determination of a new hydrophobic peptide venepeptide (1).

Cultivation of $S$. venezuelae was performed with 1 liter of ISP2 (yeast extract-malt extract) agar media. After 7 days of cultivation, cells of spore and aerial hyphae were collected by steel spatula. The cells were treated with an equal volume of $\mathrm{MeOH}$, followed by centrifugation and filtration. The $\mathrm{MeOH}$ extract was repeatedly subjected to preparative HPLC to yield the new peptide venepeptide (1 in Figure 1a, $5.0 \mathrm{mg}$, Supplementary Figure S1). After lyophilization, compound $\mathbf{1}$ had the low solubility in water, $\mathrm{MeOH}$ and acetone, but showed high solubility in dimethylsulfoxide (DMSO).

Matrix-assisted laser desorption/ionization-time-of-flight (MALDI-TOF) mass spectrum of 1 showed $[\mathrm{M}+\mathrm{H}]^{+},[\mathrm{M}+\mathrm{Na}]^{+}$ and $[\mathrm{M}+\mathrm{K}]^{+}$at $m / z 2124.18,2146.16$ and 2162.14 (Supplementary Figure S2), respectively, and the molecular formula of $\mathbf{1}$ was established to be $\mathrm{C}_{101} \mathrm{H}_{158} \mathrm{~N}_{24} \mathrm{O}_{24} \mathrm{~S}$ by the accurate mass analysis using ESI-FTCR MS $\left([\mathrm{M}+\mathrm{H}+2 \mathrm{Na}]^{3+}\right.$ at $\mathrm{m} / z$ 723.3822, calcd $[\mathrm{M}+\mathrm{H}+2 \mathrm{Na}]^{3+}$ at $\mathrm{m} / z$ 723.3819, Supplementary Figure S3). Amino acid analysis of 1 gave $1 \mathrm{~mol}$ each of Thr, Ala, Met, Ile, Phe, His, $2 \mathrm{~mol}$ each of Asp and Gly, and $4 \mathrm{~mol}$ each of Val and Leu. The attempt of direct $\mathrm{N}$-terminal protein sequencing of $\mathbf{1}$ was hampered due to the modification of the $\mathrm{N}$ terminus. To hydrolyze peptide bond of $\mathrm{C}$ terminus of Met, compound $\mathbf{1}$ was treated with cyanogen bromide $(\mathrm{CNBr})$. After $\mathrm{CNBr}$ treatment, $\mathrm{N}$-terminal protein sequencing of the cleaved peptide derived from 1 afforded the sequence of 12 amino acids (NVITNLLAGVVH). By the MALDI-TOF MS/MS experiment, the fragmented ions from 1 were of $b$-series peptides, $b 2-b 18$ except for $b 12$, from the side of $N$ terminus, and ions of $y$ series peptides, $y 5-y 17$, from the side of $C$ terminus (Figure 1b). We concluded the sequence of 1 was MNVITNLLAGVVHFLGWLV, with consideration of the results of amino acid analysis and N-terminal protein sequencing.

To obtain further information on the chemical structure, NMR spectra of 1 including ${ }^{1} \mathrm{H},{ }^{13} \mathrm{C}, \mathrm{HMBC}$, HSQC, TOCSY, DQF-COSY and NOESY were recorded using DMSO- $d_{6}$ as a solvent (Supplementary Figures S4-S10). The assignments of all the 19 amino acids constituting the peptide were completed using spin system identification and sequential assignment ${ }^{18}$ from the twodimensional (2D) NMR spectra (Table 1). The characteristic chemical shifts of formyl residue were observed at ${ }^{1} \mathrm{H} 8.00$ p.p.m. and ${ }^{13} \mathrm{C}$

${ }^{1}$ Graduate school of Agriculture, Shizuoka University, Suruga-ku, Shizuoka, Japan; ${ }^{2}$ Graduate School of Science and Technology, Shizuoka University, Suruga-ku, Shizuoka, Japan and ${ }^{3}$ National Food Research Institute, NARO, Tsukuba, Ibaraki, Japan

Correspondence: Dr S Kodani, Graduate school of Agriculture, Shizuoka University, 836 Ohya, Suruga-ku, Shizuoka 422-8529, Japan.

E-mail: askodan@ipc.shizuoka.ac.jp

Received 4 March 2014; revised 21 April 2014; accepted 22 May 2014; published online 25 June 2014 


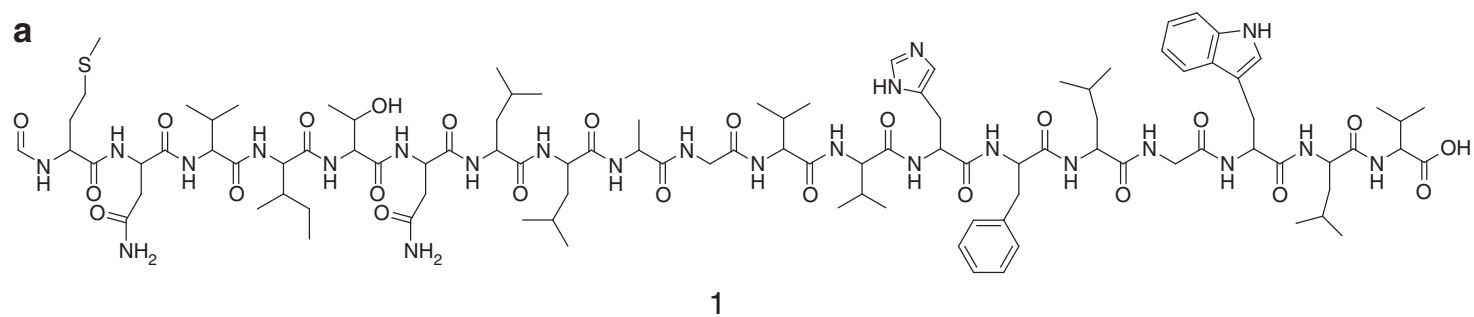

b

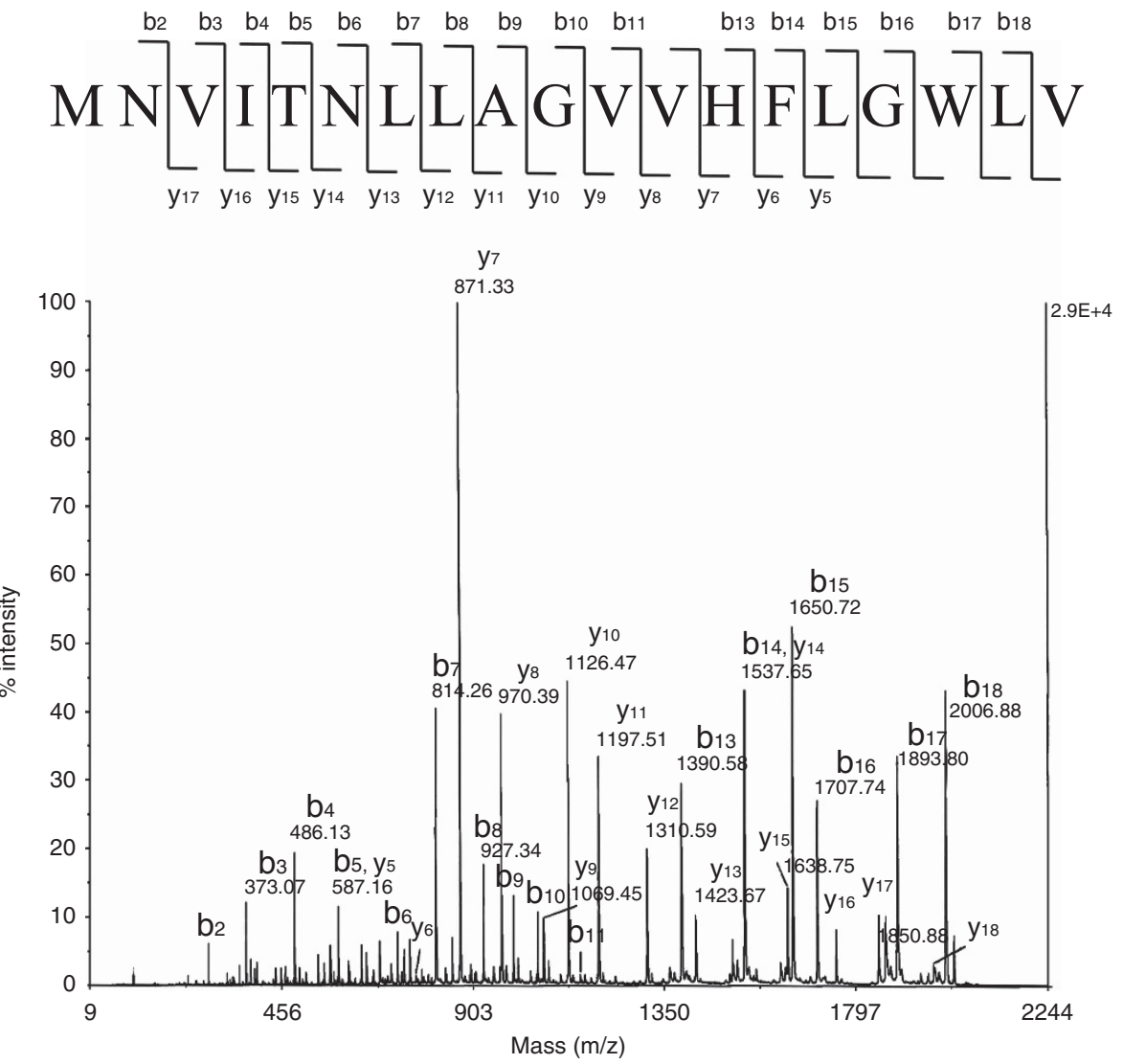

Figure 1 (a) Chemical structure of venepeptide (1), (b) MALDI-TOF MS/MS analysis on $\mathbf{1}$.

161.1 p.p.m. by HSQC spectrum. The cross peak between formyl residue ( 8.00 p.p.m.) and amide proton of Met (8.31 p.p.m.) was observed in both TOCSY and NOESY spectra, respectively, which indicated the N-terminal formylation. Above all, the chemical structure of venepeptide was determined as $\mathrm{N}$-formylated 19 amino acid peptide (1), shown in Figure 1.

The genome search using tblastn program ${ }^{19,20}$ on the web gave venepeptide coding gene, which started from starting codon (ATG, 905700-905698th DNA residue) to ending codon (TGA, 905643905641st DNA residue) on the complete genome sequence of S. venezuelae. The gene was flanked between genes SVEN_0784 (protein YceG) and SVEN_0785 (putative ABC transporter). The tblastn search seeking for venepeptide analogs revealed possible biosynthetic gene distribution over other six streptomycetes, as shown in Figure 2. The expected venepeptide analogs seemed highly conserved based on the fact that $63 \%$ (12/19 residues) of amino acids were identical among the peptides. Venepeptide had high hydrophobic amino acid content (14 residues per 19 total amino acids; 73\%), while SapB had comparatively less hydrophobic amino acid content (6 residues per 21 total amino acids; $28 \%){ }^{8}$
The hydrophobic regions were well conserved over the other six expected peptides from genome data (shown with underbars in Figure 2), which gave the idea that these peptides also may have similar physiological characteristic and function in streptomycetes as same as morphogenetic hydrophobic peptide SapB. Therefore, we evaluated the aerial hyphae formation activity of 1 to $S$. venezulelae following previous report. ${ }^{8,16}$ Unlike SapB and SapT, compound 1 did not show aerial hyphae formation activity.

To evaluate the antimicrobial activity of $\mathbf{1}$, paper disc method was performed. However, compound $\mathbf{1}$ did not show any antimicrobial activity against the microorganisms (Escherichia coli, Pseudomonas aeruginosa, Bacillus subtilis, Bacillus amyloliquefaciens, Staphylococcus aureus, Micrococcus luteus, Saccharomyces cerevisiae, Kloeckera apiculata Aspergillus niger, Aspergillus oryzae and Mucor hiemalis) at the inoculation of $50 \mu \mathrm{g}$ per disc.

In this experiment, we could not find any biological function of venepeptide. However, production of venepeptide was not observed when S. venezuelae was cultured by liquid ISP2 medium (data not shown). This phenomenon may indicate the involvement of this hydrophobic peptide to development of aerial hyphae and spore. 
Table 1 Proton chemical shifts (in p.p.m.) of venepeptide (1) in DMSO- $d_{6}\left(25^{\circ} \mathrm{C}\right)$

Chemical shit of

\begin{tabular}{|c|c|c|c|c|}
\hline Assignment & $\mathrm{NH}$ & $H A$ & $H B(M B)$ & Others \\
\hline f-Met $1^{a}$ & 8.31 & 4.42 & $1.74,1.87$ & HG 2.38 formyl-H 8.00 \\
\hline Asn2 & 8.32 & 4.57 & $2.40,2.51$ & HD2 $6.90,7.35$ \\
\hline Val3 & 7.63 & 4.18 & 1.95 & MG 0.78 \\
\hline Ile4 & 7.95 & 4.19 & 1.75 & HG1 1.08, 1.42 MG 0.80 MD 0.79 \\
\hline Thr5 & 7.73 & 4.18 & 3.92 & MG 0.98 \\
\hline Asn6 & 7.91 & 4.53 & $2.45,2.56$ & HD2 6.95, 7.46 \\
\hline Leu7 & 8.02 & 4.12 & 1.45 & HG 1.60 MD 0.79, 0.84 \\
\hline Leu8 & 7.85 & 4.20 & $1.47,1.53$ & HG 1.58 MD 0.78 \\
\hline Ala9 & 7.64 & 4.16 & 1.20 & \\
\hline Gly10 & 8.02 & $3.66,3.76$ & & \\
\hline Val11 & 7.62 & 4.18 & 1.92 & MG 0.75 \\
\hline Val12 & 7.83 & 4.03 & 1.87 & MG 0.74 \\
\hline His 13 & 7.93 & 4.48 & $2.80,2.85$ & HD2 7.70 HE1 7.63 \\
\hline Phe14 & 8.04 & 4.50 & $2.77,3.01$ & HD 7.14 HE 7.16 HZ 7.10 \\
\hline Leu15 & 8.35 & 4.24 & 1.43 & HG 1.54 MD 0.78 \\
\hline Gly16 & 7.87 & $3.54,3.70$ & & \\
\hline Trp17 & 7.95 & 4.55 & $2.91,3.12$ & $\begin{array}{l}\text { HD1 } 7.11 \text { HE1 } 10.75 \text { HE3 } 7.57 \\
\text { HZ2 } 7.28 \text { HZ3 } 6.94 \text { HH2 } 7.03\end{array}$ \\
\hline Leu18 & 8.14 & 4.37 & 1.46 & HG 1.58 MD 0.82 \\
\hline Val19 & 7.77 & 4.12 & 2.03 & MG 0.85 \\
\hline
\end{tabular}

${ }^{a}$ Formyl-methionine.

The further molecular biological experiments such as gene disruption and/or gene expression analyses are needed to clarify the physiological function of the hydrophobic peptide.

\section{EXPERIMENTAL PROCEDURE}

Strains of microorganism

All strains of microorganisms (bacterial strains including E. coli NBRC 100220, P. aeruginosa NBRC 12689, B. subtilis NBRC 13719, B. amyloliquefaciens NBRC 3007 , S. aureus NBRC 100910, M. luteus NBRC 3333, S. venezuelae NBRC 13096; Yeast strains including S. cerevisiae NBRC 2376, K. apiculata NBRC 0154; fungi strains including A. niger NBRC 33023, A. oryzae NBRC 4290, M. hiemalis NBRC 9405) were obtained from the NBRC culture collection (NITE Biological Resource Center, Japan).

\section{Isolation of venezuelapeptide}

Based on previous report, ${ }^{21}$ ISP2 (yeast extract-malt extract) agar medium (1 liter) was used for culture of S. venezuelae. After 7 days, culture at $30^{\circ} \mathrm{C}$, cells of spore and aerial hyphae were collected by steel spatel. For extraction, equal volume of methanol was added to the collected cells. After centrifugation at 3000 r.p.m. for $10 \mathrm{~min}$, the supernatant was filtered by syringe filter (Ekicrodisk 25, diameter $25 \mathrm{~mm}$, pore size $0.2 \mu \mathrm{m}$, Nihon Pall, Tokyo, Japan). The filtrated extract was repeatedly subjected to reversed-phase HPLC using ODS column (Cosmosil C18-MSII $4.6 \times 250 \mathrm{~mm}$, Nacalai Tesque, Kyoto, Japan) with isocratic elution of $85 \% \mathrm{MeCN}$ containing $0.05 \%$ trifluoroacetic acid. The UV detector of HPLC was set at the absorbance of $220 \mathrm{~nm}$ to yield venepeptide (1, $5.0 \mathrm{mg}$, retention time: $13.18 \mathrm{~min}$, Supplementary Figure S1).

\section{Amino acid analysis}

According to the reported method, ${ }^{22-24}$ amino acid content of venepeptide was determined by HPLC analysis of phenylthiocarbamyl (PTC)-derivatized amino acids. For hydrolysis, venepeptide $(0.1 \mathrm{mg})$ was incubated in $100 \mu \mathrm{l}$ of $6 \mathrm{~N} \mathrm{HCl}$ at $110{ }^{\circ} \mathrm{C}$ for $16 \mathrm{~h}$. Aliquot of $40 \mu \mathrm{l}$ of hydrolyzed sample or aliquot of $10 \mu \mathrm{l}$ of amino acid mixture standard solution (Wako Pure Chemical Industries, Tokyo, Japan) was evaporated by a freeze dryer. Aliquots of $20 \mu \mathrm{l}$ of ethanol/water/ triethylamine $(2 / 2 / 1, \mathrm{v} / \mathrm{v} / \mathrm{v})$ were added to each sample and evaporated by a
Venepeptide (Streptomyces venezuelae) AL939112 (Streptomyces coelicolor) AP009493 (Streptomyces griseus) AF170880 (Streptomyces niveus) CP005080 (Streptomyces fulvissimus) AY787762 (Streptomyces filamentosus)

FQ859185 (Streptomyces cattleya)

MNVITNLLAGVVHFLGWLV $\overline{M N} L L \bar{T} D I \overline{L A G} L \overline{V H F} V \overline{G W L}$

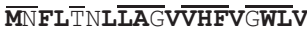

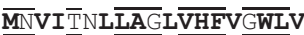
MNELTNL $\overline{L A G} I \overline{V H F} V \overline{G W L V}$ MNFLTNL LAGVVHFV GWLV $\overline{\mathrm{MN}} L V \overline{\mathrm{T}} S L \overline{\mathrm{LAG}} \mathrm{\overline { \textrm {LHF } }} \mathrm{L} \overline{\mathrm{GWL}} \mathrm{I}$

Figure 2 Alignment of venepeptide analogs expected by search from genome database. Accession numbers of peptides are indicated with parenthesized origin. Hydrophobic amino acids are indicated with bold letters, and conserved amino acids are shown with underbars.

freeze dryer. For PTC derivatization of amino acids, aliquots of $50 \mu \mathrm{l}$ of ethanol/ water/triethylamine/phenylisocyanate $(7 / 1 / 1 / 1, \mathrm{v} / \mathrm{v} / \mathrm{v} / \mathrm{v})$ were added to each sample, and derivatization was accomplished by incubation at room temperature for $20 \mathrm{~min}$. After evaporation using a freeze dryer, $1.0 \mathrm{ml}$ of PTC-derivatized amino acid mobile phase A (Wako Pure Chemical Industries) was added to dissolve each sample. The PTC-derivatized samples were analyzed using an HPLC system (PU980 system, JASCO, Tokyo, Japan). The conditions for HPLC analysis were as following: HPLC column, Wakosil PTC $(4.0 \mathrm{~mm} \times$ 200 mm; Wako Pure Chemical Industries); mobile phase A, PTC-amino acid mobile phase A (Wako Pure Chemical Industries); mobile phase B, PTC-amino acid mobile phase B (Wako Pure Chemical Industries); flow rate, $1 \mathrm{ml} \mathrm{min}^{-1}$; gradient of mobile phase B, 5 to $75 \%$ from 0 to $15 \mathrm{~min}$ (linear gradient), 75 to $100 \%$ from 15 to $20 \mathrm{~min}$ (linear gradient); UV detector, $254 \mathrm{~nm}$.

\section{Treatment of cyanogen bromide}

Venepeptide $(0.5 \mathrm{mg})$ was dissolved in $1 \mathrm{ml}$ of $70 \% \mathrm{HCOOH}$ and treated for $4 \mathrm{~h}$ at room temparature with $0.1 \mathrm{M} \mathrm{CNBr}$. After cleavage, the reaction mixture was centrifuged at 14500 r.p.m. and the supernatant was concentrated by rotary evaporator and completely lyophilized by a freeze dryer. The residue was re-dissolved in $0.5 \mathrm{ml}$ of methanol and subjected to reversed-phase HPLC separation using ODS column (Cosmosil C18-MSII $4.6 \times 250 \mathrm{~mm}$, Nacalai Tesque) with isocratic elution of $80 \% \mathrm{MeCN}$ containing $0.05 \%$ trifluoroacetic acid. The UV detector of HPLC was set at the absorbance of $220 \mathrm{~nm}$ to yield cleaved venepeptide.

\section{BLAST search}

The analogous genomic and amino acidic sequences of venepeptide were obtained by searching against non-redundant NCBI databases (http:// www.ncbi.nlm.nih.gov/BLAST). ${ }^{19,20}$

\section{Analysis of the $\mathrm{N}$-terminal protein sequence}

Purified peptides were subjected to amino acid sequencing on a protein sequencer PPSQ-21A (Shimadzu, Kyoto, Japan) according to the procedure provided by the manufacturer.

\section{NMR experiments}

A NMR sample was prepared by dissolving the purified peptide in $500 \mu \mathrm{l}$ of DMSO- $d_{6}$. All ${ }^{1} \mathrm{H}-\mathrm{NMR}$ spectra were obtained on Bruker DRX600 and Avance 800 spectrometers with quadrature detection in the phase-sensitive mode by time proportional phase incrementation ${ }^{25}$ and States-time proportional phase incrementation. ${ }^{26}$ The following spectra were recorded at $25^{\circ} \mathrm{C}$ and $30^{\circ} \mathrm{C}$ with 15 p.p.m. spectral widths in $t 1$ and $t 2$ dimensions: 2D DQF-COSY, recorded with 512 and 2048 complex points in $t 1$ and $t 2$ dimensions; 2D homonuclear TOCSY with DIPSI2 mixing sequence, recorded with mixing time of $80 \mathrm{~ms}, 256$ and 1024 complex points in $t 1$ and $t 2$ dimensions; 2D NOESY, recorded with mixing times of 200 and $400 \mathrm{~ms}, 512$ and 2048 complex points in $t 1$ and $t 2$ dimensions. Water suppression was performed using presaturation method. $2 \mathrm{D}{ }^{1} \mathrm{H}-{ }^{13} \mathrm{C}$ heteronuclear $\mathrm{HSQC}$ spectrum was acquired at $25^{\circ} \mathrm{C}$ in the echo-antiecho mode..$^{27}$ The ${ }^{1} \mathrm{H}-{ }^{13} \mathrm{C}$ HSQC spectrum was recorded with $1024 \times 512$ complex points for 12 p.p.m. in the ${ }^{1} \mathrm{H}$ dimension and 170 p.p.m. in the ${ }^{13} \mathrm{C}$ dimension at a natural isotope abundance.

All NMR spectra were processed using XWINNMR (Bruker Daltonics, Billerica, MA, USA). Peak-picking and assignment were performed with 
Sparky program (UCSF, http://www.cgl.ucsf.edu/Research/Sparky.html). Before FT, the shifted sinebell window function was applied to $t 1$ and $t 2$ dimensions. All ${ }^{1} \mathrm{H}$ and ${ }^{13} \mathrm{C}$ dimensions were referenced to DMSO- $d_{6}$ at $25^{\circ} \mathrm{C}$.

\section{MS experiments}

MALDI-TOF/TOF mass spectra were recorded on a 4800 plus MALDI-TOF/ TOF analyzer (AB SCIEX, Framingham, CA, USA) using $\alpha$-cyano-4-hydroxycinnamic acid (Bruker Daltonics) as the matrix in the positive-ion mode with an acceleration voltage of $20 \mathrm{kV}$. The mass spectrometer was tuned and calibrated using a commercially available standard peptide mixture (Peptide Calibration Standard II, Bruker Daltonics) prior to the measurement. The ESI Fourier-transform ion cyclotron resonance mass spectrum was recorded on the ApexII 70e mass spectrometer (Bruker Daltonics). The sample solution was infused into the ESI source directly at $2-5 \mu \mathrm{min}^{-1}$ using a syringe pump after dilution by $50 \%$ methanol. The accurate mass measurement was done using the internal standard YOKUDELNA (JEOL, Tokyo, Japan).

\section{Aerial hyphae formation assay}

Following previous method, ${ }^{8,16} 10 \mu \mathrm{g}$ of venepeptide $\left(1 \mu \mathrm{l}\right.$ of $10 \mu \mathrm{g} \mu \mathrm{l}^{-1}$ solution in DMSO) was dropped onto agar medium after the spore cells of S. venezuelae were spread over agar plate. After the plate was incubated for $24-48 \mathrm{~h}$ at $30^{\circ} \mathrm{C}$, morphological appearance of grown colonies around venepeptide-inoculated point was observed visually.

\section{Antimicrobial assay}

Cultivation of testing microorganism was performed using ISP2 agar medium at $37^{\circ} \mathrm{C}$ for $24 \mathrm{~h}$. Paper disc (i.d. $8 \mathrm{~mm}$, thin type for $50 \mu \mathrm{g}$ ) was used to disc diffusion assay following previous report. ${ }^{28}$ After plates were incubated for $24-48 \mathrm{~h}$ at $30^{\circ} \mathrm{C}$, inhibitory zones were observed visually.

\section{ACKNOWLEDGEMENTS}

This study was supported by the Japan Society for the Promotion of Science by Grants-in-aids (grant number 25350964). We thank Dr Tomohiro Suzuki for accomplishing $\mathrm{N}$ terminus protein sequencing.

1 Galm, U. et al. Comparative analysis of the biosynthetic gene clusters and pathways for three structurally related antitumor antibiotics: bleomycin, tallysomycin, and zorbamycin. J. Nat. Prod. 74, 526-536 (2011)

2 Liu, G., Chater, K. F., Chandra, G., Niu, G. \& Tan, H. Molecular regulation of antibiotic biosynthesis in streptomyces. Microbiol. Mol. Biol. Rev. 77, 112-143 (2013).

3 Goto, Y. et al. Discovery of unique lanthionine synthetases reveals new mechanistic and evolutionary insights. PLoS Biol. 8, e1000339 (2010)

4 Hranueli, D., Cullum, J., Basrak, B., Goldstein, P. \& Long, P. F. Plasticity of the streptomyces genome-evolution and engineering of new antibiotics. Curr. Med. Chem. 12, 1697-1704 (2005)

5 Nguyen, K. T. et al. A central regulator of morphological differentiation in the multicellular bacterium Streptomyces coelicolor. Mol. Microbiol. 46, 1223-1238 (2002).
6 Willey, J., Santamaria, R., Guijarro, J., Geistlich, M. \& Losick, R. Extracellular complementation of a developmental mutation implicates a small sporulation protein in aerial mycelium formation by S. coelicolor. Cell 65, 641-650 (1991).

7 Willey, J., Schwedock, J. \& Losick, R. Multiple extracellular signals govern the production of a morphogenetic protein involved in aerial mycelium formation by Streptomyces coelicolor. Genes Dev. 7, 895-903 (1993).

8 Kodani, S. et al. The SapB morphogen is a lantibiotic-like peptide derived from the product of the developmental gene ramS in Streptomyces coelicolor. Proc. Natl Acad. Sci. USA 101, 11448-11453 (2004).

9 Willey, J. M. \& Gaskell, A. A. Morphogenetic signaling molecules of the streptomycetes. Chem. Rev. 111, 174-187 (2011).

10 Elliot, M. A. et al. The chaplins: a family of hydrophobic cell-surface proteins involved in aerial mycelium formation in Streptomyces coelicolor. Genes Dev. 17, 1727-1740 (2003)

11 Capstick, D. S., Willey, J. M., Buttner, M. J. \& Elliot, M. A. SapB and the chaplins: connections between morphogenetic proteins in Streptomyces coelicolor. Mol. Microbiol. 64, 602-613 (2007).

12 Claessen, D. et al. The formation of the rodlet layer of streptomycetes is the result of the interplay between rodlins and chaplins. Mol. Microbiol. 53, 433-443 (2004).

13 de Jong, W., Vijgenboom, E., Dijkhuizen, L., Wosten, H. A. \& Claessen, D. SapB and the rodlins are required for development of Streptomyces coelicolor in high osmolarity media. FEMS Microbiol. Lett. 329, 154-159 (2012).

14 Willey, J. M. \& Gaskell, A. A. Morphogenetic signaling molecules of the streptomycetes. Chem. Rev. 111, 174-187 (2011).

15 Willey, J. M., Willems, A., Kodani, S. \& Nodwell, J. R. Morphogenetic surfactants and their role in the formation of aerial hyphae in Streptomyces coelicolor. Mol. Microbiol. 59, 731-742 (2006)

16 Kodani, S., Lodato, M. A., Durrant, M. C., Picart, F. \& Willey, J. M. SapT, a lanthioninecontaining peptide involved in aerial hyphae formation in the streptomycetes. Mol. Microbiol. 58, 1368-1380 (2005)

17 Voller, G. H. et al. Characterization of new class III lantibiotics-erythreapeptin, avermipeptin and griseopeptin from Saccharopolyspora erythraea, Streptomyces avermitilis and Streptomyces griseus demonstrates stepwise $\mathrm{N}$-terminal leader processing. Chembiochem. 13, 1174-1183 (2012).

18 Wüthrich, K. NMR of Proteins and Nucleic Acids (Wiley, New York, 1986).

19 Altschul, S. F. et al. Gapped BLAST and PSI-BLAST: a new generation of protein database search programs. Nucleic Acids Res. 25, 3389-3402 (1997).

20 Zhang, Z., Schwartz, S., Wagner, L. \& Miller, W. A greedy algorithm for aligning DNA sequences. J. Comput. Biol. 7, 203-214 (2000)

21 Shirling, E. B. \& Gottlieb, D. Methods for characterization of Streptomyces species. Int J. Syst. Bacteriol. 16, 313-340 (1966).

22 Bidlingmeyer, B. A., Cohen, S. A. \& Tarvin, T. L. Rapid analysis of amino acids using pre-column derivatization. J. Chromatogr. 336, 93-104 (1984).

23 Cohen, S. A., Bidlingmeyer, B. A. \& Tarvin, T. L. PITC derivatives in amino acid analysis. Nature 320, 769-770 (1986).

24 Heinrikson, R. L. \& Meredith, S. C. Amino acid analysis by reverse-phase highperformance liquid chromatography: precolumn derivatization with phenylisothiocyanate. Anal. Biochem. 136, 65-74 (1984).

25 Marion, D. \& Wuthrich, K. Application of phase sensitive two-dimensional correlated spectroscopy (COSY) for measurements of ${ }^{1} \mathrm{H}_{-}{ }^{1} \mathrm{H}$ spin-spin coupling constants in proteins. Biochem. Biophys. Res. Commun. 113, 967-974 (1983).

26 Marion, D., Ikura, M., Tschudin, R. \& Bax, A. Rapid recording of 2D nmr-spectra without phase bycling - application to the study of hydrogen-exchange in proteins. J. Magn. Reson. 85, 393-399 (1989).

27 Kay, L. E., Keifer, P. \& Saarinen, T. Pure absorption gradient enhanced heteronuclea single quantum correlation spectroscopy with improved sensitivity. J. Am. Chem. Soc 114, 10663-10665 (1992)

28 Kodani, S., Murao, A., Hidaki, M., Sato, K. \& Ogawa, N. Isolation and structura determination of a new macrolide, makinolide, from the newly isolated Streptomyces sp. MK-30. J. Antibiot. (Tokyo) 65, 331-334 (2012).

Supplementary Information accompanies the paper on The Journal of Antibiotics website (http://www.nature.com/ja) 